\title{
育苗中の移植が茄子・蕃茄の花芽分化，花芽 の發育並に開花結實に及ぼす影響に就で
}

$\begin{array}{llll}\text { 江 口 } & \text { 伭 } & \text { 雄 } \\ \text { 高 } & \text { 川 治 } & \text { 久 } \\ \text { 谷 } & \text { 川 } & & \text { 茂 }\end{array}$

(仕葉涼等園學學校)

\section{I. 緒 言}

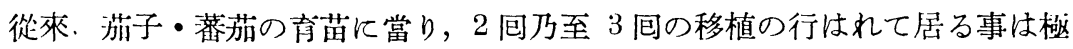
く一般的な事であって，移植操作は花芽形成を促し，引沙ては開花，收檴期を 早めるものかの如き考への下に, 必要以上の移植を行ひ, 中には, 茄子・蕃茄 が比較的移植に强してとから，萠を萎らして省みないやうな隨分微暴な育萠の 行はれて居る事も屡与見受ける事である。

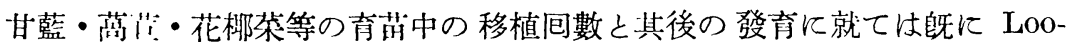

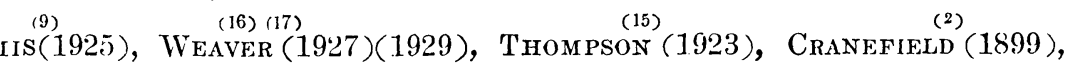
(8)
年 授(1934), 石黑 $(1935)$, 志佐(1937) 年等の實驗があつて，其の多くは移植操作 は何等積極的の效果無き而巳ならす寧ろ negative の作用を及将す事が述べら れて居る。

篗者等は是等果茶類の花芽が既に育萠中に形成されて居る事に鑑み，育苗中 の移植操作が花芽分化期，分化數，開花期，收量飞如何䄈る影響を及将すかを 知らんが雼め昭和 $11-12$ 年に本實驗を行つたものである。

\section{II. 材料及方法}

4 尺× 12 尺の木柜に一般法に準じて播種し，適它間引して，第 1 表に示す 如く略与 15 日每に第 1 回から第 3 回迄の移植區を作り各區其方 5 寸距離と爲

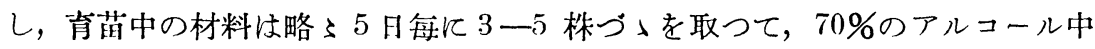

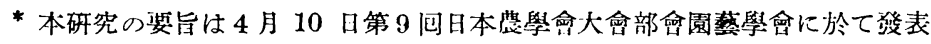


に保存して適宜實驗に供し，育苗中の管理は一般法に準じて行つた。

第 1 表 播 種, 移植, 定 植 期

昭和 11 年

\begin{tabular}{|c|c|c|c|c|c|c|c|}
\hline 種 & 類 操 作 期 & 播 & 種 & 第 1 回移植 & 第 2 氤移植 & 第 3 回移植 & 定 \\
\hline 蕃 & 茄 (Cater's fruit) & 3 月 & 5 日 & 4月 8 日 & 4月 20 日 & 5 月 4 日 & 5 月 12 日 \\
\hline 茄 & 子(畺 & 3 月 & 5 日 & 4月 6 日 & 4月 20 日 & 5 月 3 日 & 5 月 15 日 \\
\hline
\end{tabular}

昭和 12 年

\begin{tabular}{|c|c|c|c|c|c|c|c|c|c|}
\hline 蕃 & 茄 (Cater's & fruit) & 3 月 15 日 & 4月 & 5 日 & 4 月 20 日 & 5 月 & 3 日 & 5 月 15 日 \\
\hline 茄 & 子 (畺 & 黑) & 3月 15 日 & 4月 & 5 日 & 4 月 20 日 & 5 月 & 5 日 & 5 月 16 日 \\
\hline
\end{tabular}

\section{III. 䁈 驗 結 果}

（1）花芽分化標徽

茄子・蕃茄共に播種後 30-40日，本葉 2-3 枚開序した時，外部より 8 枚 一9 枚の葉及始原葉を取り除くと內部成長點に達する, 內部成長點の變化郎花 芽分化の標徽は筆者が今日迄に取扱つて來た一般園藝作物の場合と略ら同樣， 頂點が肥大肥厚して蓦片の初生突起を生じて花芽分化期に達し，始原某 $2-3$ 枚を增す每に相次んで第 2 ，第 3 の果房を形成する（第 1 ，第 2，第 3，第 4 圖參照)。

\section{（2）花芽分化期飞及㤬す影響}

(a) 悉 茄

昭和 11 年 (3 月 5 日蒔) に於ける移植包數と第 1 , 第 2 , 第 3 果房の花芽 分化期との闆係を表示すれば第 2 表に示す通りである。

第2表 花芽分化期比較表 (1936, トマト)

\begin{tabular}{|c|c|c|c|c|c|c|c|c|c|c|c|c|c|c|c|}
\hline 別 & 果 居 & 所要 & $\begin{array}{l}\text { 月 } \\
\mathbf{3 . 2} \\
\end{array}$ & 4. 1 & 4 & 8 & 12 & 16 & 20 & 24 & 28 & 5. 2 & 6 & 10 & 12 \\
\hline 無移植區 & 第 1 果房 & $31^{\text {月 }}$ & $x$ & $\Delta$ & 0 & 0 & & & & & & & & & \\
\hline 無移植區 & 第 $\mathbf{2}$ 果房 & 47 & & & & $x$ & $x$ & $\Delta$ & 0 & 0 & & & & & \\
\hline 1 包移植區 & " & 51 & & & & & $x$ & $x$ & $\Delta$ & 0 & 0 & & & & \\
\hline 2 包移植區 & " & 59 & & & & & & & & $x$ & $x$ & 0 & 0 & & \\
\hline 無移植區 & 第 3 果房 & 55 & & & & & & $x$ & $x$ & $\triangle$ & 0 & 0 & & & \\
\hline 1 包移植區 & " & 59 & & & & & & & $x$ & $x$ & $\Delta$ & 0 & 0 & & \\
\hline 2 回移植偘 & $v$ & 67 & & & & & & & & $x$ & $x$ & $\Delta$ & $\Delta$ & 0 & 0 \\
\hline 3 包移植區 & " & 71 & & & & & & & & & & $x$ & $x$ & $\Delta$ & 0 \\
\hline
\end{tabular}

供考 $\times \cdots$ 未分化 $\Delta \cdot \cdots$ 分化初期 $\bigcirc \cdots$ 分化期 
以上に依れば此の年の第 1 包移植は 4 月 8 日に行はれ既に第 1 果房は 4 月 4 日に形成されて居た。從つて移植の影響は第 1 果房に及ばず，第 2 ，第 3 の果 房に影響して夫ょ 5--10 日花芽分化期を後らして居る。

昭和 12 年 (3 月 15 日蒔) 飞於ける移植包數と各果房の花芽分化期との關 係を表示すれば第 3 表に示す通りである。

第 3 表 花芽分化期表 (1937，トマト)

\begin{tabular}{|c|c|c|c|c|c|c|c|c|c|c|c|c|}
\hline 別 & 房 & 所要日數 & ค. ${ }_{1}^{H}$ & 5 & 10 & 15 & 20 & 25 & 30 & 5. 5 & 10 & 15 \\
\hline 無移植澏 & 第 1 果房 & 31 & $x$ & $x$ & $\Delta$ & 0 & 0 & $\bigcirc$ & 0 & 0 & $O$ & O \\
\hline 1 回移植區 & II & 36 & & & $x$ & $\triangle$ & 0 & $\mathrm{O}$ & 0 & 0 & 0 & 0 \\
\hline 無移植區 & 第 2 果房 & 41 & & & & $\times$ & $\Delta$ & 0 & 0 & 0 & $O$ & $\mathrm{O}$ \\
\hline 1 回移植區 & " & 46 & & & & $x$ & $x$ & $\Delta$ & 0 & 0 & 0 & 0 \\
\hline 2 回移植區 & " & 46 & & & & & & $x$ & 0 & 0 & 0 & 0 \\
\hline 無移植澏 & 第 3 果房 & 51 & & & & & & & $\Delta$ & 0 & 0 & 0 \\
\hline 1 包移植區 & " & 51 & & & & & & & $x$ & 0 & 0 & 0 \\
\hline 2 包移植愠 & " & 56 & & & & & & & $x$ & $\Delta$ & 0 & 0 \\
\hline 3 包移植區 & " & 61 & & & & & & & & & $x$ & 0 \\
\hline 無移植區 & 第 4 果房 & 61 & & & & & & & & & $\Delta$ & 0 \\
\hline 1 包移植區 & " & 61 & & & & & & & & & $\Delta$ & 0 \\
\hline 2 可移植區 & " & - & & & & & & & & & $x$ & $\Delta$ \\
\hline 3 问移植區 & " & - & & & & & & & & & & $x$ \\
\hline
\end{tabular}

借考 $\times \cdots$ 未分化 $\Delta \cdot \cdots$ 分化初期 $\bigcirc \cdots$ 分化期

以上飞依れば昭和 12 年の第 1 果房の花芽分化期は 4 月 15 日であつて第 1 包移植は 4 月 5 日郎花芽分化前 10 日に篇され此時の移植操作は第 1 果房の分 化期に影響して 1 包移植區は無移植區に比較して約 5 日程分化期後れ第 2 ，第 3 ，第 4 果房子夫々移植包數を燴す每に5-10 日後れて居る。
(b) 茄
子

昭和 11 年 (3月 5 日蒔) 飞於ける移植包數と各果房の花芽分化期との關係 を表示すれば第 4 表に示す通りである。

第 4 表 花芽分化期比較表 (1936，茄子)

\begin{tabular}{|c|c|c|c|c|c|c|c|c|c|c|c|c|c|}
\hline & 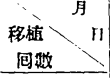 & 4. 12 & 14 & 16 & 19 & 21 & 24 & 29 & 5. 3 & 5 & 10 & 13 & 15 \\
\hline 采 & 0 & 0 & 0 & 0 & 0 & 0 & 0 & 0 & 0 & 0 & 0 & 0 & 0 \\
\hline 花 & 1 & & $x$ & 0 & 0 & 0 & 0 & - & 0 & 0 & 0 & 0 & 0 \\
\hline
\end{tabular}




\begin{tabular}{|c|c|c|c|c|c|c|c|c|c|c|c|c|}
\hline & \begin{tabular}{l|l} 
月 \\
移植 \\
回致
\end{tabular} & 14 & 16 & 19 & 21 & 24 & 29 & 5. 3 & 5 & 10 & 13 & 15 \\
\hline - & 0 & $x$ & $\times$ & $\times$ & 0 & 0 & 0 & 0 & 0 & 0 & 0 & 0 \\
\hline $\overrightarrow{\text { s }}$ & 1 & $x$ & $x$ & $x$ & $x$ & $x$ & - & 0 & 0 & 0 & 0 & 0 \\
\hline 饰 & 2 & & & & $x$ & $x$ & $x$ & $x$ & 0 & 0 & 0 & 0 \\
\hline & 3 & & & & & & & $x$ & 0 & 0 & 0 & 0 \\
\hline$=$ & 0 & $x$ & $x$ & $x$ & $x$ & $x$ & $x$ & 0 & 0 & 0 & 0 & 0 \\
\hline 采 & 1 & $x$ & $x$ & $x$ & $x$ & $x$ & - & $x$ & $x$ & 0 & 0 & 0 \\
\hline tis & 2 & & & & $x$ & $x$ & $x$ & $x$ & $x$ & $x$ & $x$ & 0 \\
\hline 化 & 3 & & & & & & & $x$ & $x$ & $x$ & $x$ & $x$ \\
\hline
\end{tabular}

游考 $\times$. 沫分化 $\mathrm{O} \cdot$.分化

以上に依れば昭和 11 年の 1 番花の花牙分化期は 4 月 12 日で第 1 包の移植 は 4 月 6 日即花芽分化前 6 日に爲され，此時の移植操作は 1 番花の分化期に影 響して 4 日程後れ，2 番花，3 番花も夫ょ移植包數を菂す每に 5-10 日程後 れて居る。

昭和 12 年 (3 月 15 日蒔) に於ける移植闹數と各果原の花芽分化期との關 係に於て夕（第 9 表參热）無移植區は 4 月 12 日（播種後 38 日）に 1 番花形 成され，1 包移植區は約 10 日後れて 4 月 30 日稍了前に分化し，2 番花，3 番花も移植包數を增す每に头々5-10 日花牙分化期が後れて居る。

(c) 要 約

以上に依れば茄子・蕃茄共に移植操作は花牙分化期に惡影響を及壮し，第 1 ， 第 2 , 第 3 果房其に移植包數を增す每に5-10 日花牙分化期を後らして居 る（第 1, 2, 3, 4 圖參监)。

（3）花牙の發育に及将す影響(1)

移植间數が花芽の發育に及ばす影響に就いて得た結果は第 5 ，第 6 ，第 7 ， 第 8 ，第 9 ，第 10 表に示す通りである。 
第 5 表 花芽分化期並花芽の發育表

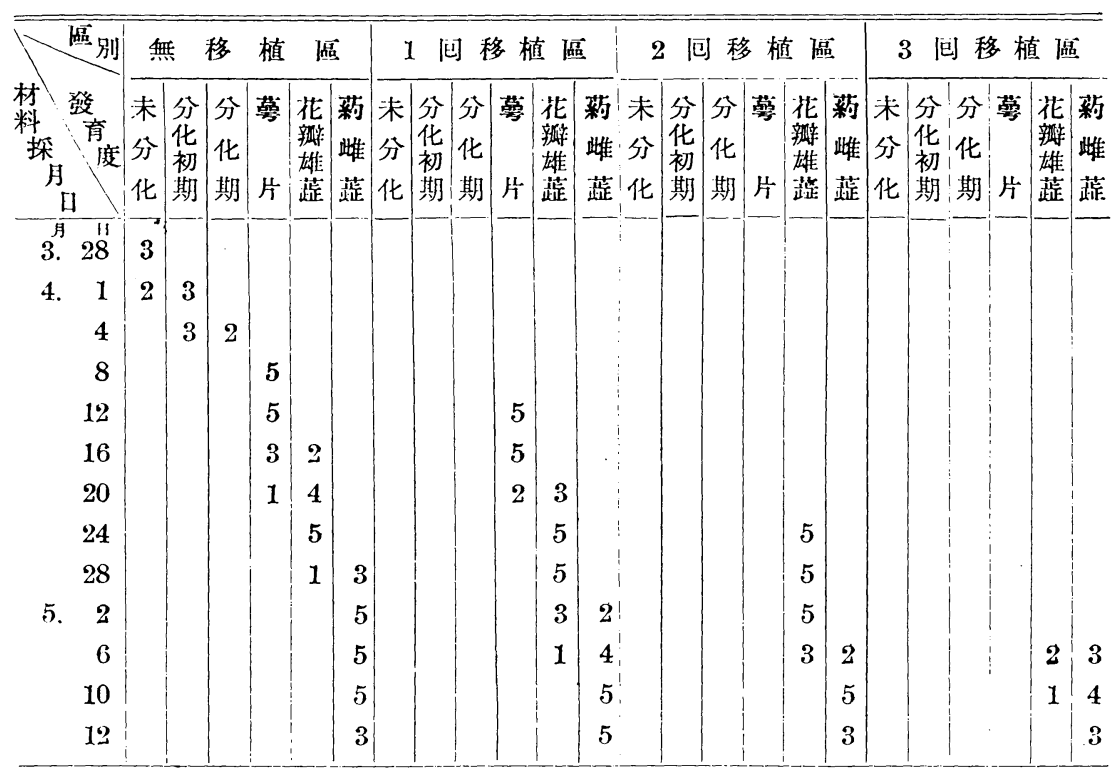

第 2 朵 房

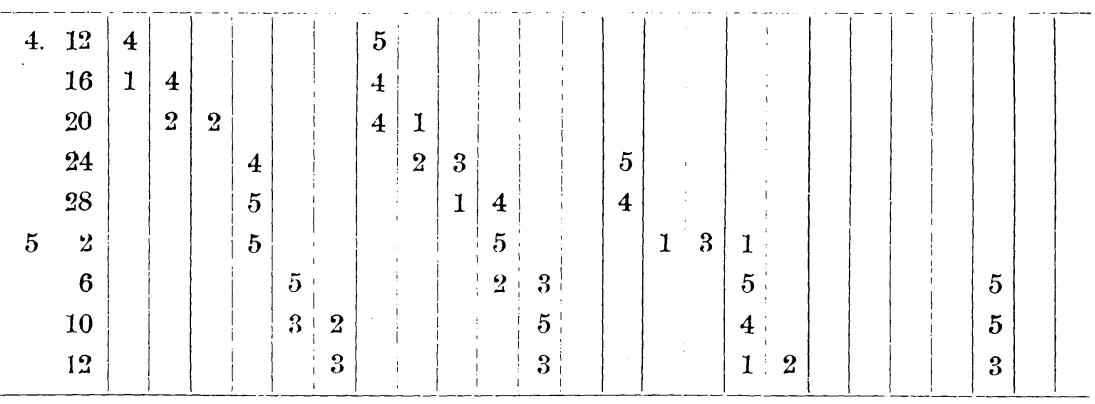

第 3 果 房

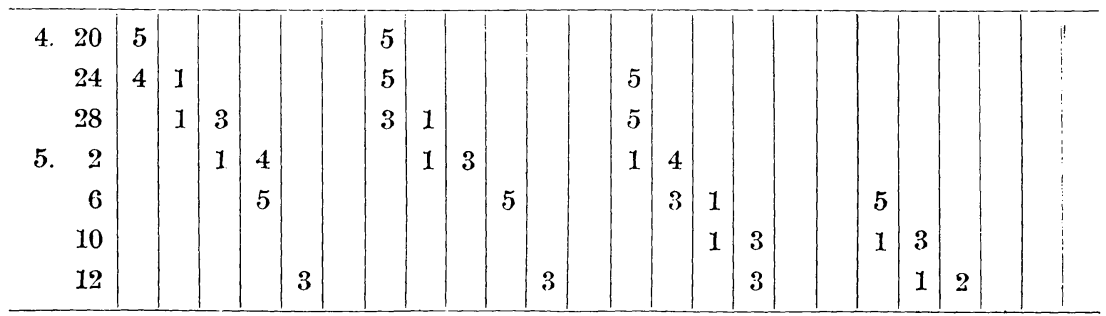


第 6 表 花芽分化期並花芽發育表（第 1 果房）（1937，トマト）

\begin{tabular}{|c|c|c|c|c|c|c|c|c|c|c|c|c|c|c|c|c|c|c|c|c|c|c|c|c|}
\hline \multirow{2}{*}{ 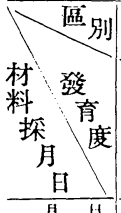 } & \multicolumn{3}{|c|}{ 無 } & \multicolumn{3}{|c|}{ 植 温 } & \multicolumn{6}{|c|}{1 包移植區 } & \multicolumn{6}{|c|}{2 问移植區 } & \multicolumn{6}{|c|}{3 包移植區 } \\
\hline & $\begin{array}{l}\text { 未 } \\
\text { 分 } \\
\text { 化 }\end{array}$ & $\begin{array}{l}\text { 分 } \\
\text { 华 } \\
\text { 初 }\end{array}$ & $\begin{array}{l}\text { 分 } \\
\text { 化 } \\
\text { 期 }\end{array}$ & 片 & 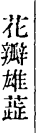 & $\begin{array}{l}\text { 菞 } \\
\text { 雌 } \\
\text { 㸺 }\end{array}$ & $\begin{array}{l}\text { 未 } \\
\text { 分 } \\
\text { 化 }\end{array}$ & & $\begin{array}{l}\text { 分 } \\
\text { 化 } \\
\text { 期 }\end{array}$ & 片 & 花 & 葙 & $\begin{array}{l}\text { 未 } \\
\text { 分 } \\
\text { 化 }\end{array}$ & $\begin{array}{l}\text { 分 } \\
\text { 化 } \\
\text { 初 }\end{array}$ & $\begin{array}{l}\text { 分 } \\
\text { t } \\
\text { 封 }\end{array}$ & 楞 & 花 & $\begin{array}{l}\text { 葱 } \\
\text { 雌 } \\
\text { 龁 }\end{array}$ & $\begin{array}{l}\text { 未 } \\
\text { 分 } \\
\text { 化 }\end{array}$ & 分 & $\begin{array}{l}\text { 分 } \\
\text { 化 } \\
\text { 期 }\end{array}$ & 片 & 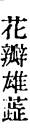 & 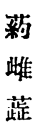 \\
\hline \begin{tabular}{rr|} 
月 & H \\
4. & 5
\end{tabular} & 5 & & & & & & & & & & & & & & & & & & & & & & & \\
\hline 10 & 3 & 1 & & & & & 3 & 1 & & & & & & & & & & & & & & & & \\
\hline 15 & 1 & 2 & & 2 & & & 2 & 1 & & 2 & & & & & & & & & & & & & & \\
\hline 20 & & & & 1 & 3 & 1 & & 1 & & 3 & 1 & & & & & & & & & & & & & \\
\hline 25 & & & & 2 & & 3 & & & 1 & 1 & 1 & 2 & & 2 & & 2 & 1 & & & & & & & \\
\hline 30 & & & & & & 4 & & & & & 1 & 4 & & & & & 2 & 3 & & & & & & \\
\hline 5. 5 & & & & & & 4 & & & & & & 4 & & & & & 1 & 4 & & & & & & \\
\hline 10 & & & & & & 5 & & & & & & 5 & & & & & & 5 & & & & & & 5 \\
\hline 15 & & & & & & 5 & & & & & & 5 & & & & & & 5 & & & & & & 5 \\
\hline
\end{tabular}

第 7 表 花芽分化期及發育表 (第 2 果房) (1937，トマト)

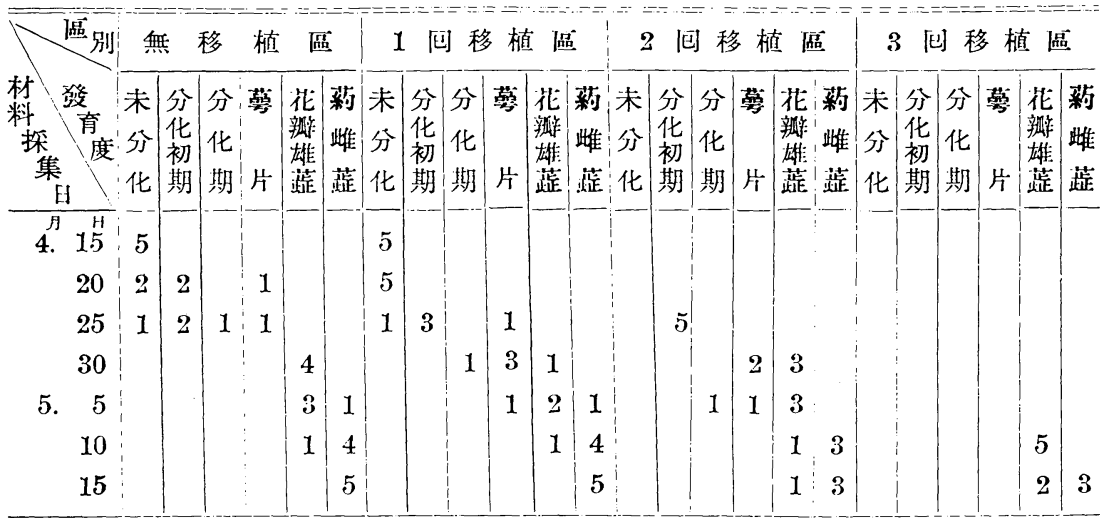

第 8 表 花芽分化期並發育表（第 3 果居）(1937，トマト)

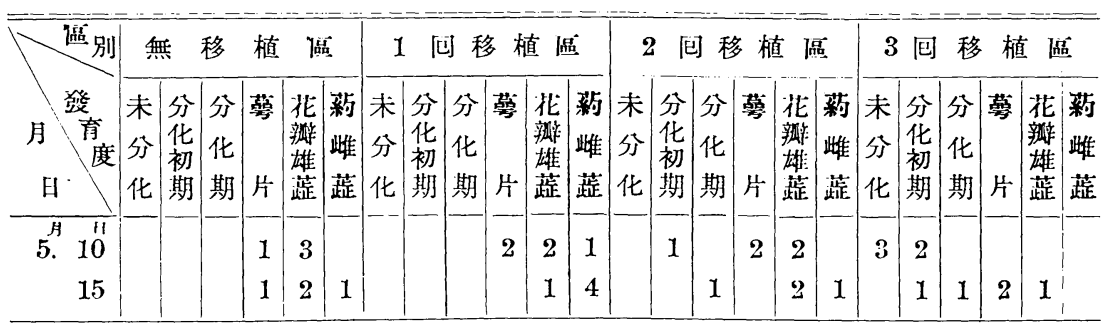

第 4 果 房

\begin{tabular}{rr|l|l|l|l|l|l|l|l|l|l|l|l|l|l|l|l|l|} 
5. & 10 & 1 & 3 \\
15 & 1 & & 3 & & & 4 & 1 & & & & & 3 & 1 & & & & & \\
2
\end{tabular}


第 9 表 花芽分化期並花芽發育表（第 1 番花) (1937，茄子)

\begin{tabular}{|c|c|c|c|c|c|c|c|c|c|c|c|c|c|c|c|c|c|c|c|c|c|c|c|c|}
\hline 留名 & 無 & & 移 & 植 & 强 & & & 10 & 可 移 & 植 & 直 & & & $1 E$ & 匀 移 & 多植 & 湂 & & & 咸 & 移 & 植 & 闾 & \\
\hline $\begin{array}{c}\text { 探 } \\
\text { 集 } \\
\text { 日 }\end{array}$ & $\begin{array}{l}\text { 未 } \\
\text { 分 } \\
\text { 化 }\end{array}$ & $\begin{array}{l}\text { 分 } \\
\text { 化 } \\
\text { 期 }\end{array}$ & $\begin{array}{l}\text { 蒡 } \\
\text { 年 } \\
\text { 形 } \\
\text { 成 }\end{array}$ & \begin{tabular}{|l|} 
花 \\
溯 \\
形 \\
战
\end{tabular} & $\begin{array}{l}\text { 雄 } \\
\text { 莜 } \\
\text { 形 } \\
\text { 成 }\end{array}$ & \begin{tabular}{|} 
雌 \\
荹 \\
形 \\
成
\end{tabular} & $\begin{array}{l}\text { 未 } \\
\text { 分 } \\
\text { 化 }\end{array}$ & $\begin{array}{l}\text { 分 } \\
\text { 化 } \\
\text { 期 }\end{array}$ & $\begin{array}{l}\text { 营 } \\
\text { 片 } \\
\text { 形 } \\
\text { 成 }\end{array}$ & $\begin{array}{l}\text { 花 } \\
\text { 泒 } \\
\text { 刑 } \\
\text { 成 }\end{array}$ & $\begin{array}{l}\text { 雄 } \\
\text { 笓 } \\
\text { 形 }\end{array}$ & $\begin{array}{l}\text { 雌 } \\
\text { 战 } \\
\text { 形 } \\
\text { 戊 }\end{array}$ & $\begin{array}{l}\text { 未 } \\
\text { 分 } \\
\text { 化 }\end{array}$ & $\begin{array}{l}\text { 分 } \\
\text { 化 } \\
\text { 期 }\end{array}$ & $\begin{array}{l}\text { 㢣 } \\
\text { 形 } \\
\text { 战 }\end{array}$ & \begin{tabular}{|l|} 
花 \\
称 \\
形 \\
战
\end{tabular} & $\begin{array}{l}\text { 雄 } \\
\text { 䇛 } \\
\text { 形 } \\
\text { 战 }\end{array}$ & 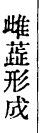 & $\begin{array}{l}\text { 未 } \\
\text { 分 } \\
\text { 化 }\end{array}$ & $\begin{array}{l}\text { 分 } \\
\text { 化 } \\
\text { 期 }\end{array}$ & $\begin{array}{l}\text { 萦 } \\
\text { 章 } \\
\text { 形 } \\
\text { 戊 }\end{array}$ & 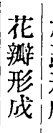 & 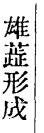 & 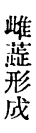 \\
\hline $\begin{array}{rr}{ }^{A} & H \\
4 . \quad 5 \\
10 \\
15 \\
20 \\
25 \\
25 \\
30 \\
5 . \quad 5 \\
10 \\
15\end{array}$ & $\begin{array}{l}5 \\
5 \\
5\end{array}$ & 1 & 3 & $\begin{array}{l}1 \\
2 \\
3\end{array}$ & 4 & 4 & 5 & & 2 & 3 & 5 & 5 & 2 & 1 & $\begin{array}{l}2 \\
1 \\
1\end{array}$ & $\begin{array}{l}3 \\
3 \\
1\end{array}$ & 4 & & & & 1 & & $\begin{array}{l}2 \\
4\end{array}$ & \\
\hline
\end{tabular}

第 10 表 花芽分化期並花芽發育表 (第 2 番花) (1937，茄-子)

\begin{tabular}{|c|c|c|c|c|c|c|c|c|c|c|c|c|c|c|c|c|c|c|c|c|c|c|c|c|}
\hline \multirow{2}{*}{ 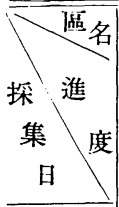 } & \multicolumn{3}{|c|}{ 無 移 } & \multicolumn{3}{|c|}{ 植 澏 } & \multicolumn{6}{|c|}{1 回移植漚 } & \multicolumn{6}{|c|}{2 回移植湂 } & \multicolumn{6}{|c|}{3 间移植區 } \\
\hline & $\begin{array}{l}\text { 未 } \\
\text { 分 } \\
\text { 化 }\end{array}$ & $\begin{array}{l}\text { 分 } \\
\text { 化 } \\
\text { 期 }\end{array}$ & $\begin{array}{l}\text { 警 } \\
\text { 号 } \\
\text { 形 } \\
\text { 战 }\end{array}$ & 花 & $\begin{array}{l}\text { 雄 } \\
\text { 蕗 } \\
\text { 形 } \\
\text { 戊 }\end{array}$ & $\begin{array}{l}\text { 雌 } \\
\text { 蔫 } \\
\text { 形 } \\
\text { 战 }\end{array}$ & $\begin{array}{l}\text { 未 } \\
\text { 分 } \\
\text { 化 }\end{array}$ & $\begin{array}{l}\text { 分 } \\
\text { 化 } \\
\text { 期 }\end{array}$ & $\begin{array}{c}\text { 辜 } \\
\text { 形 } \\
\text { 战 }\end{array}$ & $\begin{array}{l}\text { 花 } \\
\text { 瓣 } \\
\text { 形 }\end{array}$ & $\begin{array}{l}\text { 雄 } \\
\text { 荹 } \\
\text { 形 } \\
\text { 成 }\end{array}$ & 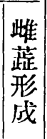 & $\begin{array}{l}\text { 未 } \\
\text { 分 } \\
\text { 化 }\end{array}$ & $\begin{array}{l}\text { 分 } \\
\text { 化 } \\
\text { 期 }\end{array}$ & $\begin{array}{l}\text { 䓪 } \\
\text { 点 } \\
\text { 形 } \\
\text { 成 }\end{array}$ & $\begin{array}{l}\text { 花 } \\
\text { 效 } \\
\text { 形 } \\
\text { 成 }\end{array}$ & $\begin{array}{l}\text { 雄 } \\
\text { 蕋 } \\
\text { 形 } \\
\text { 成 }\end{array}$ & $\begin{array}{l}\text { 雌 } \\
\text { 雌 } \\
\text { 刑 }\end{array}$ & $\begin{array}{l}\text { 未 } \\
\text { 分 } \\
\text { 化 }\end{array}$ & $\begin{array}{l}\text { 分 } \\
\text { 化 } \\
\text { 期 }\end{array}$ & 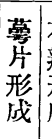 & 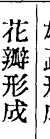 & 雄 & 雌踏 \\
\hline \begin{tabular}{rr|}
4. & 30 \\
5. & 5 \\
& 10 \\
& 15
\end{tabular} & $\begin{array}{l}4 \\
3 \\
2\end{array}$ & 1 & $\begin{array}{l}2 \\
1\end{array}$ & $\begin{array}{l}1 \\
2\end{array}$ & 2 & & 2 & 1 & 2 & 2 & 3 & & 1 & & 3 & 1 & & & & & & & & \\
\hline
\end{tabular}

以上に依れば花器形成の推移も花芽分化期と略々同樣に移植司數を賭す每に 後れ，無移植區は花牙の發育最も進んで居る。

（4）花芽の發育に及㭱す影響（2）

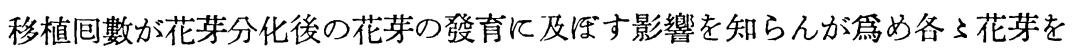
ミクロメーターにて测定して得た結果を表示すれば第 5 , 第 6 , 第 7 , 第 8 圖 に示す通りである。 


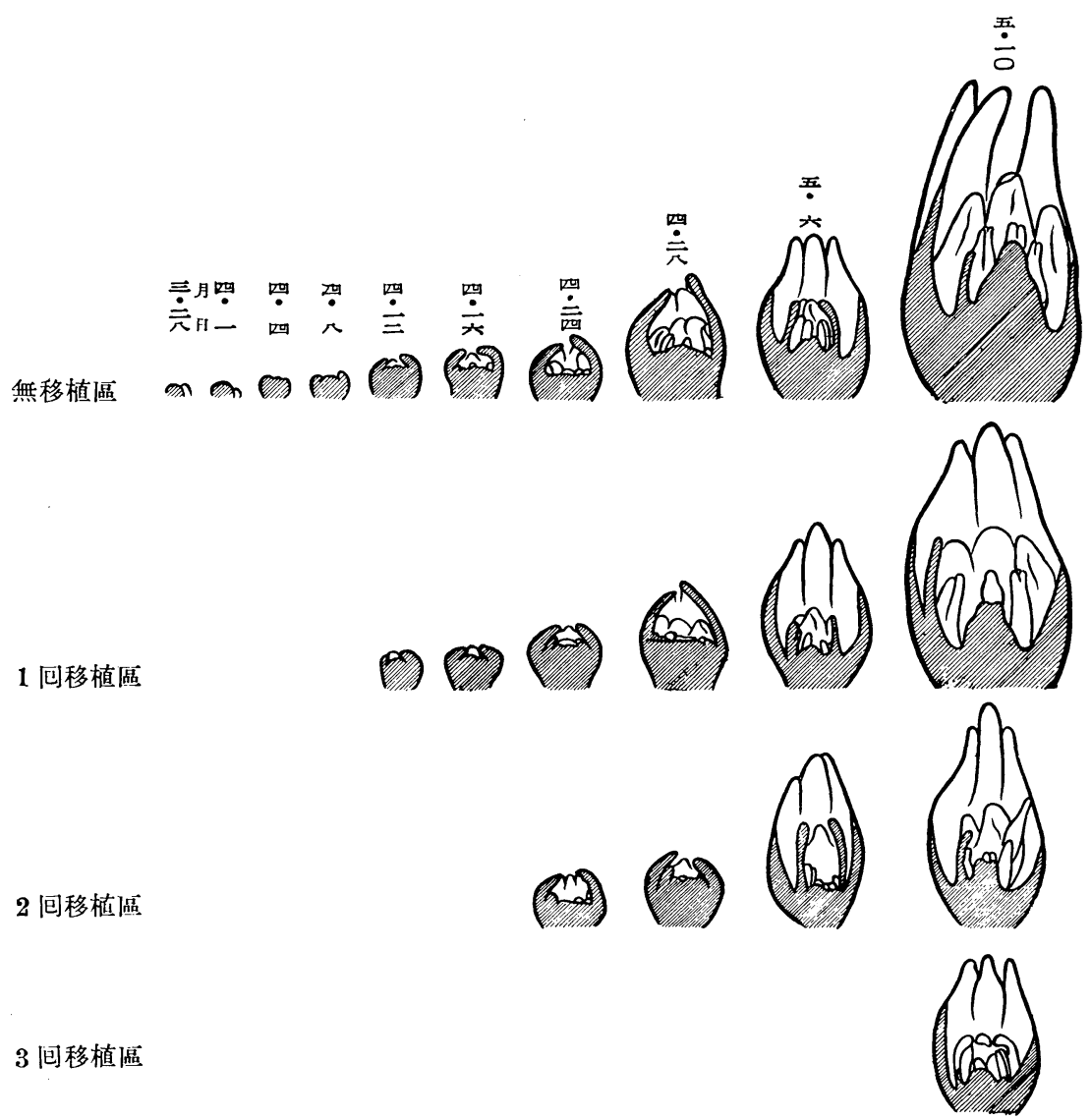

第 1 圖 移植闶數と蕃茄の花芽分化並花芽發育比較 (1936，トマト)

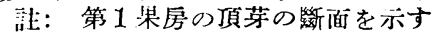

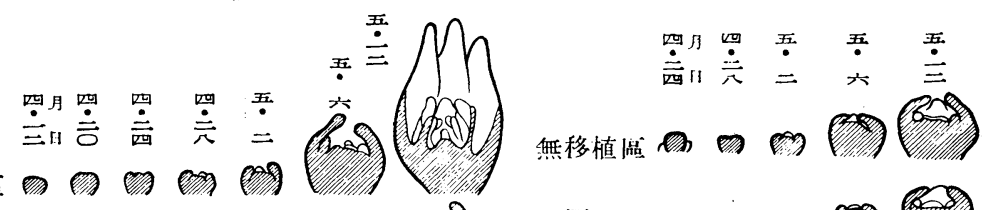

無移植湂甲 问

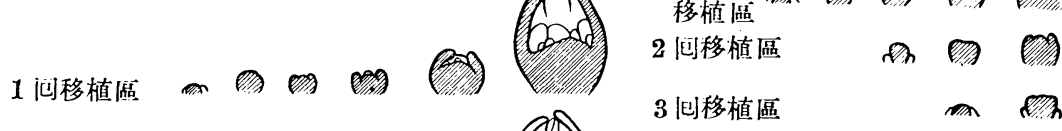

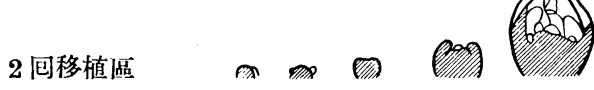

$$
\begin{aligned}
& 3 \text { 回移植區 }
\end{aligned}
$$

第 2 圖 䔟植国數々蕃茄の花芽分化並

乼：第 2 果房の頂芽の斷面を示す 


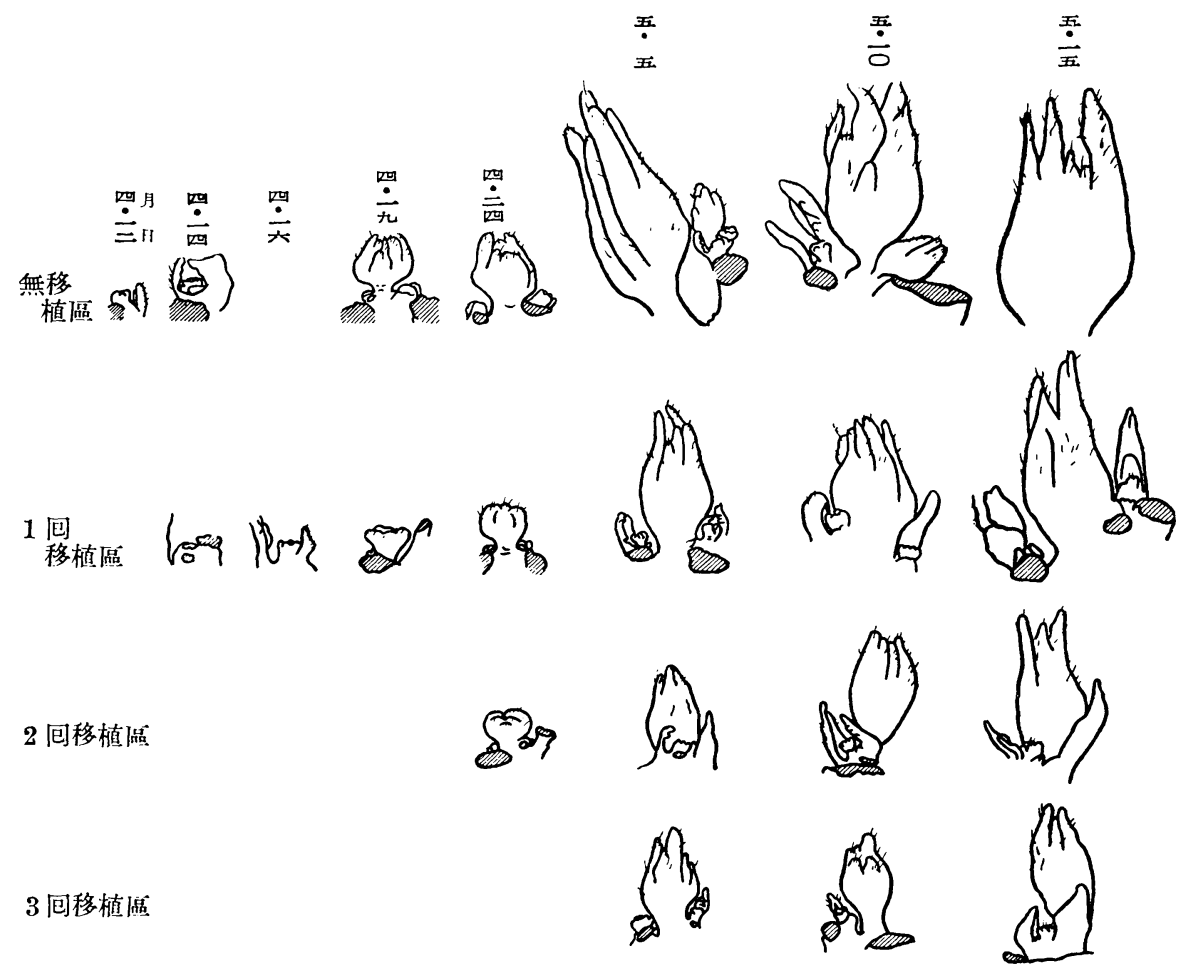

第 4 圖 移植包數と茄子の花芽分化並花芽發育比較 (1936, 茄子)

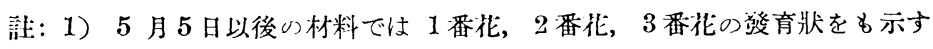

2) 茄子の 2 番北，3番北は 1 番北の形成後, 閌为無く相次いで形成される

以上に依れば蕃茄，茄子共に花芽分化期，花器形式の推移之略々同樣，花芽 の發育も移植间數を垻す短に著しく後れ，無移植區の花芽發育が最も進んで居 る。

（5）花牙分化數に及忹す影響

移植包數が蕃茄の各果房の花牙分化數に及惊す影響に就いて調べを結果は第 11，第 12 表及第 9 圖に示す通りである。 

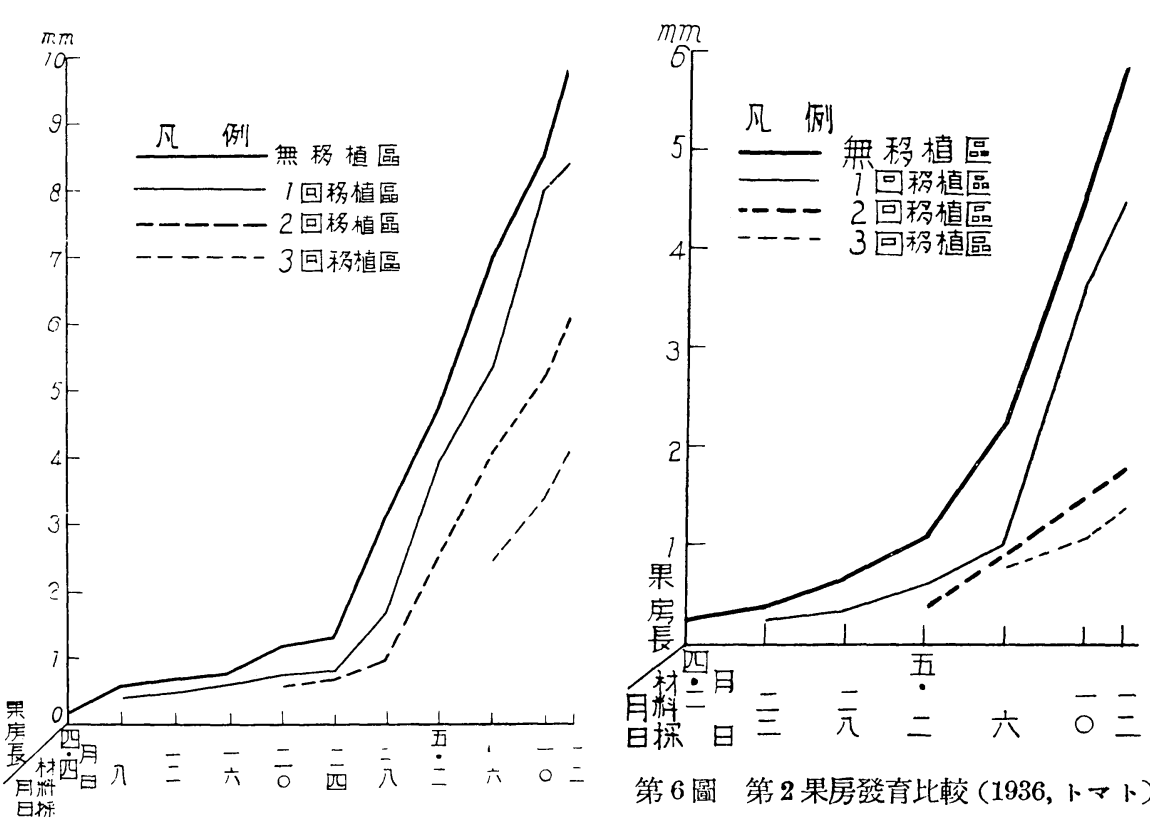

第 5 圖 第 1 果房發育比較(長) (1936, トマト)

第 6 圆 第 2 果房墢育比較 (1936,トマト)

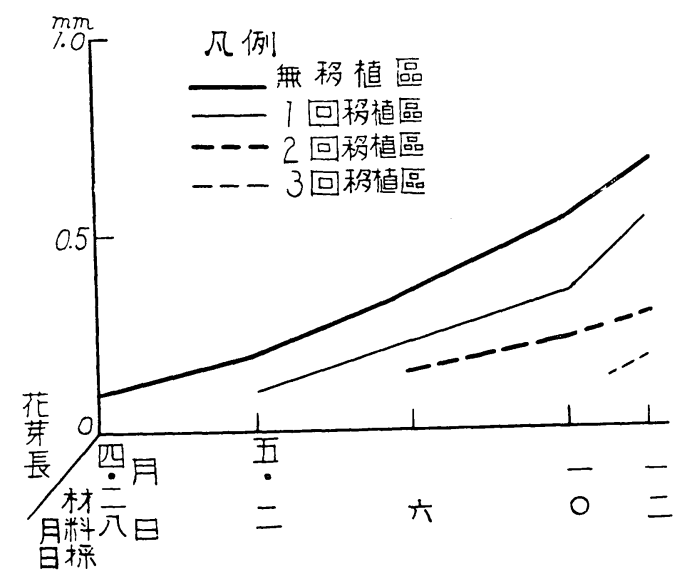

第 7 圖 第 3 果房發育比較 $(1936$, トマト)

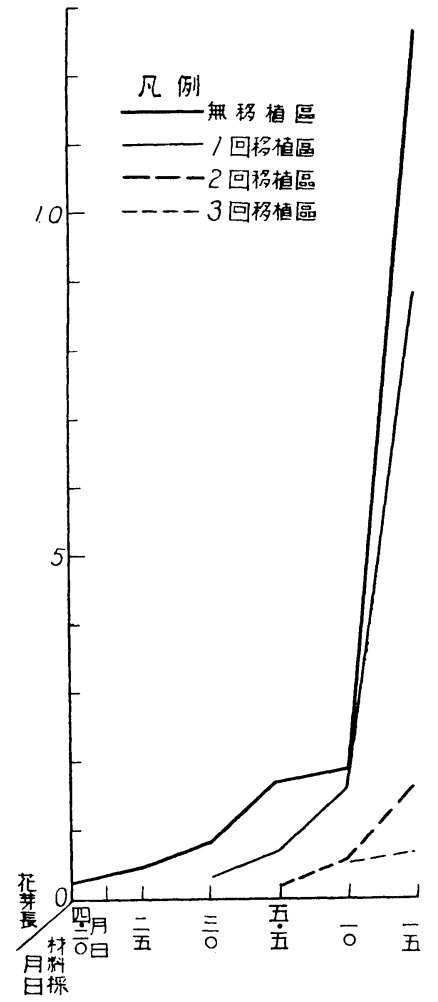

第 8 圖 花芽長比較 (1937，茄子) 
第 11 表 花芽分化數比較 (1936,トマト)

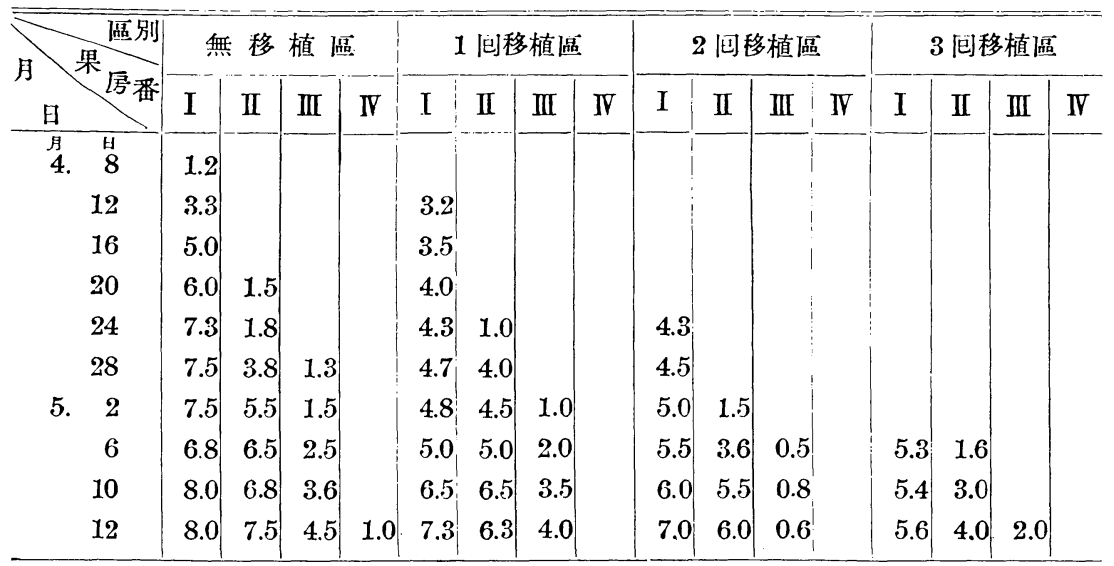

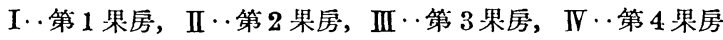

第 12 表 蕃茄花芽分化數比較表 (1937, トマト)

\begin{tabular}{|c|c|c|c|c|c|c|c|c|c|c|c|c|c|c|c|c|}
\hline \multirow{2}{*}{ 月粱冨別 } & \multicolumn{4}{|c|}{ 無移植澏 } & \multicolumn{4}{|c|}{1 包移植區 } & \multicolumn{4}{|c|}{2 回移植區 } & \multicolumn{4}{|c|}{3 问移植區 } \\
\hline & I & II & III & IV & I & II & III & IV & I & II & III & IV & I & II & III & IV \\
\hline $\begin{array}{ll}\text { 月 } & \text { 日 } \\
4 . & 15\end{array}$ & 3.4 & & & & 3.2 & & & & & & & & & & & \\
\hline 20 & 3.8 & 1.5 & & & 3.7 & & & & & & & & & & & \\
\hline 25 & 5.3 & 1.8 & & & 4.7 & 1.0 & & & 2.8 & & & & & & & \\
\hline 30 & 6.0 & 3.8 & & & 5.3 & 3.7 & & & 4.4 & 3.6 & & & & & & \\
\hline 5.5 & 7.5 & 5.5 & 3.2 & & 6.9 & 4.8 & 2.1 & & 4.6 & 3.8 & & & & & & \\
\hline 10 & 8.0 & 6.7 & 4.1 & & 7.5 & 6.2 & 3.5 & & 5.2 & 4.8 & 3.4 & & 4.9 & 3.8 & & \\
\hline 15 & 8.2 & 7.8 & 4.7 & 3.2 & 7.8 & 7.5 & 3.8 & 2.4 & 6.0 & 4.6 & 4.0 & 3.0 & 6.3 & 4.2 & 4.0 & \\
\hline
\end{tabular}

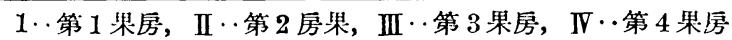

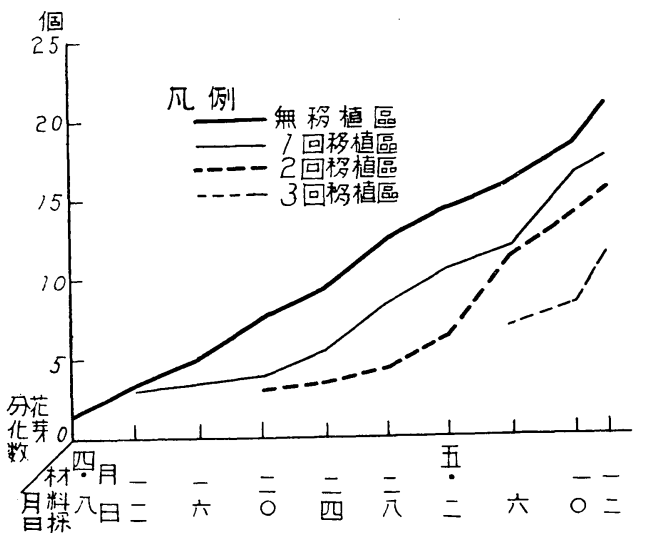

第 9 圖＼cjkstart花芽分化總數比較 (1936, トマト)
以上結果江依れば移植は， 花牙分化期, 花器形成, 花芽 の發育を避らす而巳ならず， 各果房の花芽分化數に\&影響 して移植包數を增す每に各果 房の花芽分化數を減少して居 る。此の經濟的價僧高い第 1 , 第 2 , 第 3 果房の分化數の多 少は戋場の經濟的事情から見 
て育苗上特に考虑を拂はねばならぬ點だと思ふ。

（6）花芽分化節位，草丈，葉の枚數炕及发す影響

(a) 花芽分化節位

移植可數と花芽分化節位との關係は第 13 ，第 14 ，第 15 表に示す通りであ る。

第 13 表 節位別花芽分化數 (1936,トマト)

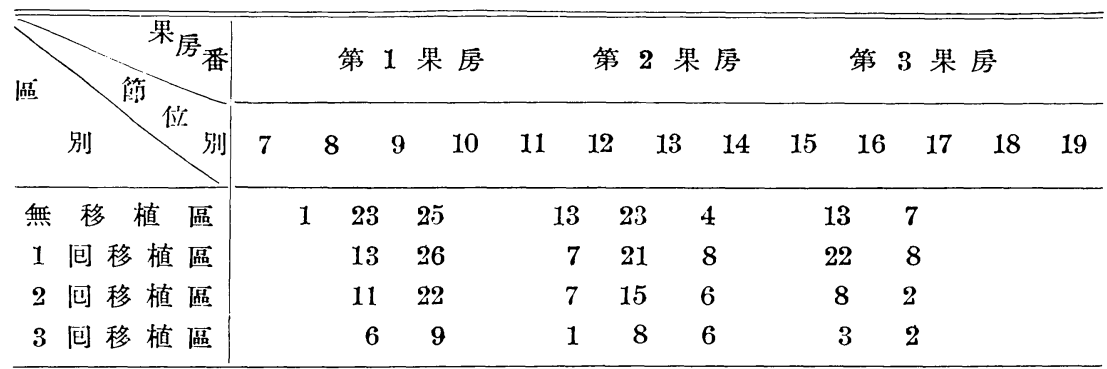

第 14 表 節位別花芽分化數 (1937，トマト)

\begin{tabular}{|c|c|c|c|c|c|c|c|c|c|c|c|c|}
\hline 果房番 & & ; 1 果 & & & 轻 2 果 & & & 第 3 果 & & & 4 果扅 & \\
\hline 位 & 8 & 9 & 10 & 11 & 12 & 13 & 14 & 15 & 16 & 17 & 18 & 19 \\
\hline 無 移 植 嵒 & 8 & & 6 & 6 & 10 & & 4 & 3 & 5 & & 1 & 2 \\
\hline 1 包移植區 & 4 & 17 & 9 & 2 & 2 & 9 & 6 & 1 & 7 & 4 & 1 & $\mathbf{3}$ \\
\hline 2 问移植區 & 8 & 4 & 11 & $\epsilon$ & 6 & 4 & 8 & 3 & & 4 & 1 & \\
\hline 3 包移植嵒 & 1 & 8 & 1 & 1 & 1 & & 8 & 1 & & 3 & & \\
\hline
\end{tabular}

第 15 表 節位別茄一の最初の花茅分化 (1936,茄子)

\begin{tabular}{|c|c|c|c|c|c|}
\hline 别 位 & $7-8$ & $8-9$ & $9-10$ & $10-11$ & 個 體 數 \\
\hline 無 移 植 區 & 8 & 36 & 3 & 0 & 47 \\
\hline 1 回移植區 & 6 & 18 & 6 & 0 & 30 \\
\hline 2 问移植澏 & 5 & 22 & 12 & 2 & 41 \\
\hline 3 问移植蛊 & 4 & 24 & 8 & 0 & 36 \\
\hline
\end{tabular}

符：茄子の笽位は甲折葉の節位を合まず數へた

以上に低れば 1936 年と 1937 年に依つて多少の相違はあつたが總じて移植 包數と花芽分化節位との間には殆んど關係無く各區共第 1 果房は第 9-10 節に 第 2 果房は第 12-13 節位に形成されて居る。 
(b) 草丈及葉の枚數

移植包數之草丈並葉の枚數との關係は，第 $10 ， 11 ， 12 ， 13 ， 14,15,16 ， 17$ ， 18，19 圖に示す通りである。

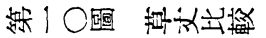

(1 Rillkस्म $\leftarrow r-)$

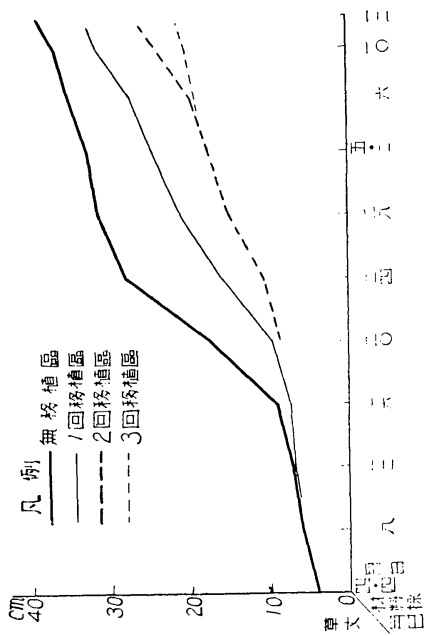

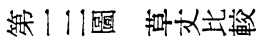

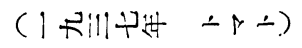

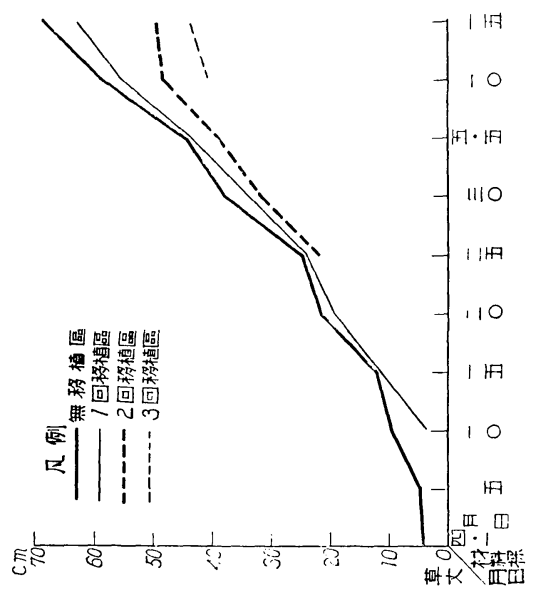

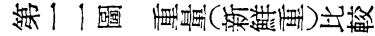

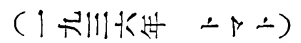

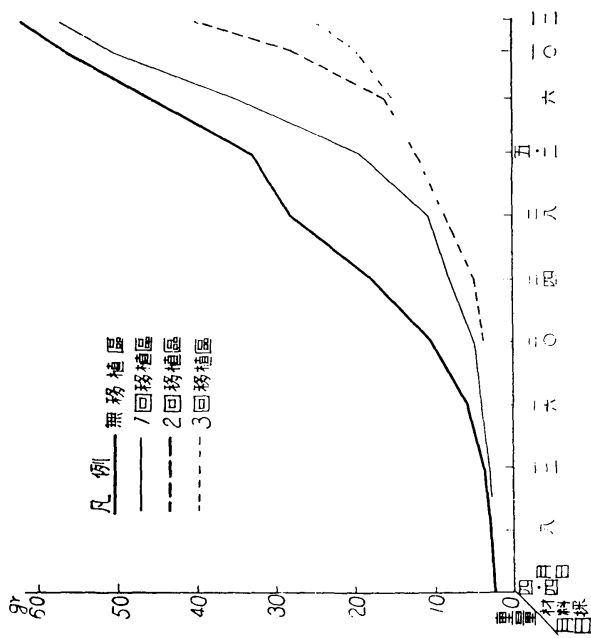

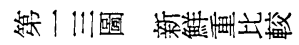

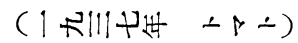

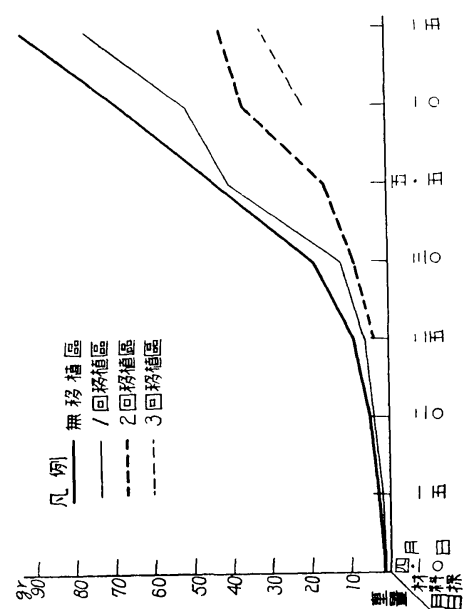




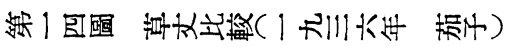

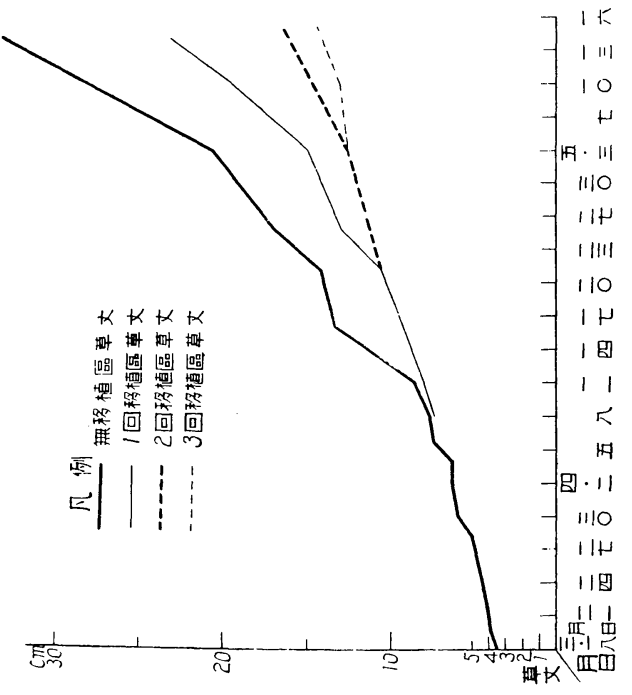

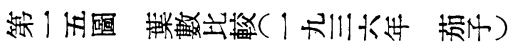

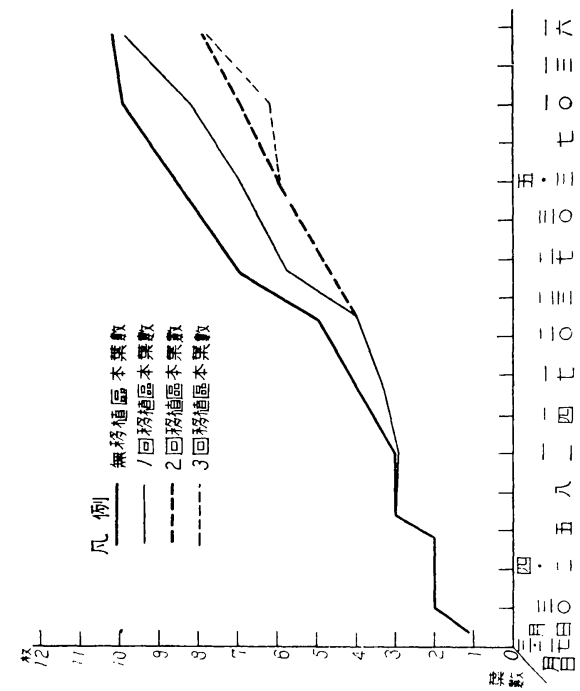

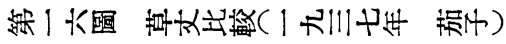

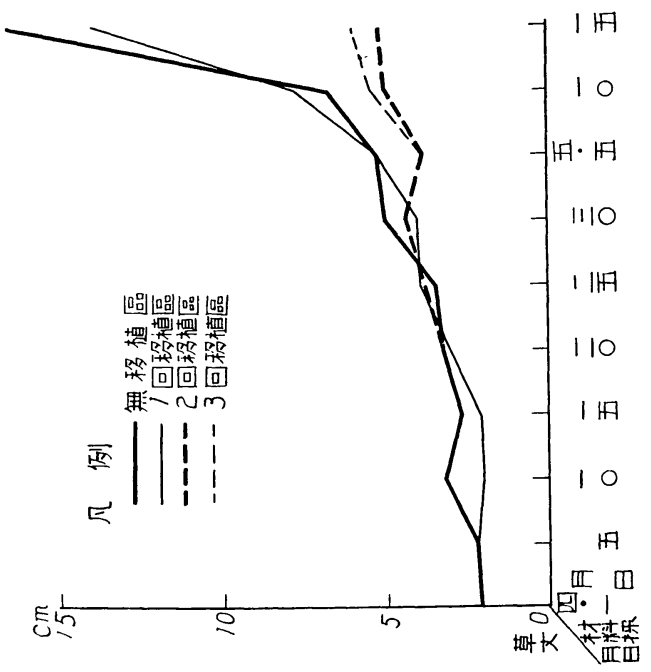

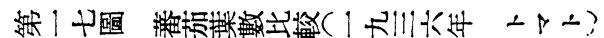

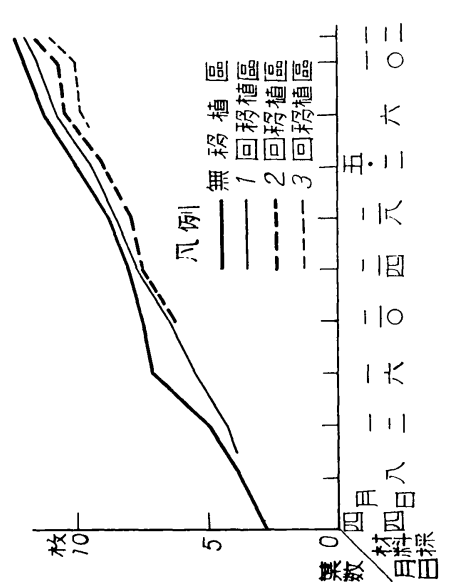




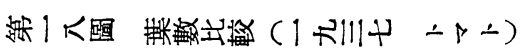

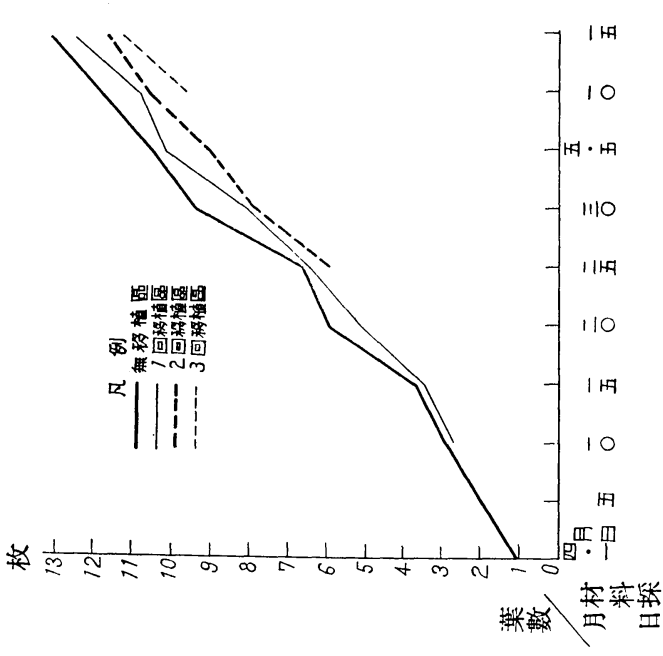

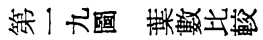

(1 RII14 标(t)

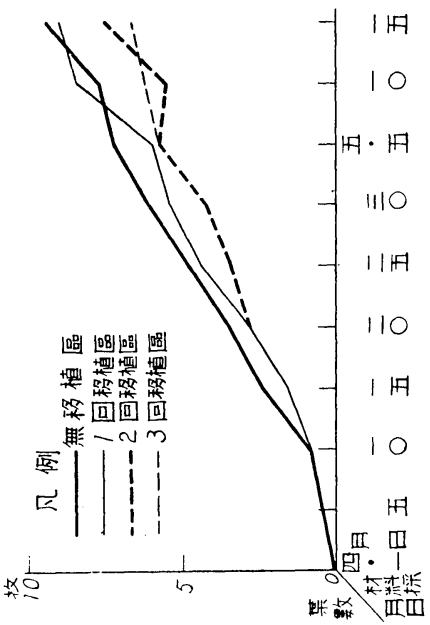

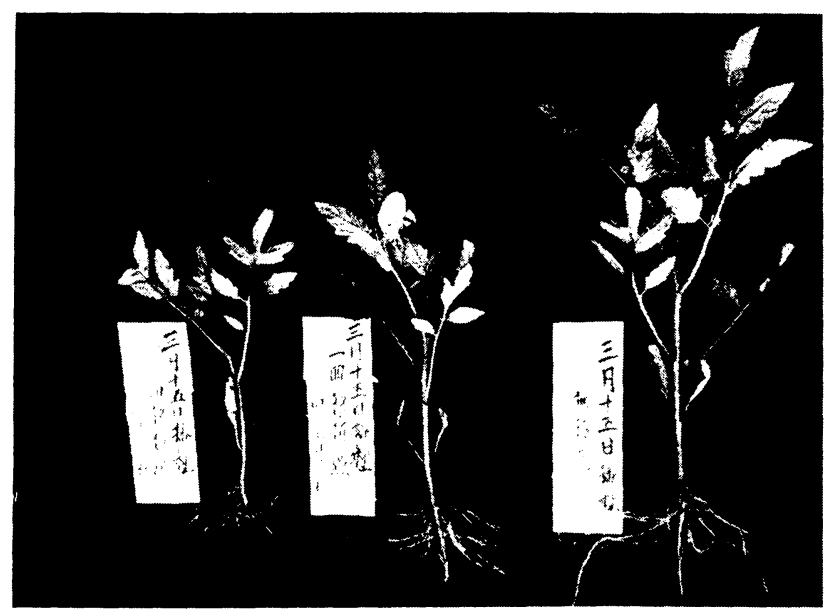

第 20 圖 育苗中に於ける各移植區の苗の發育を示す (1937. 4. 25) 


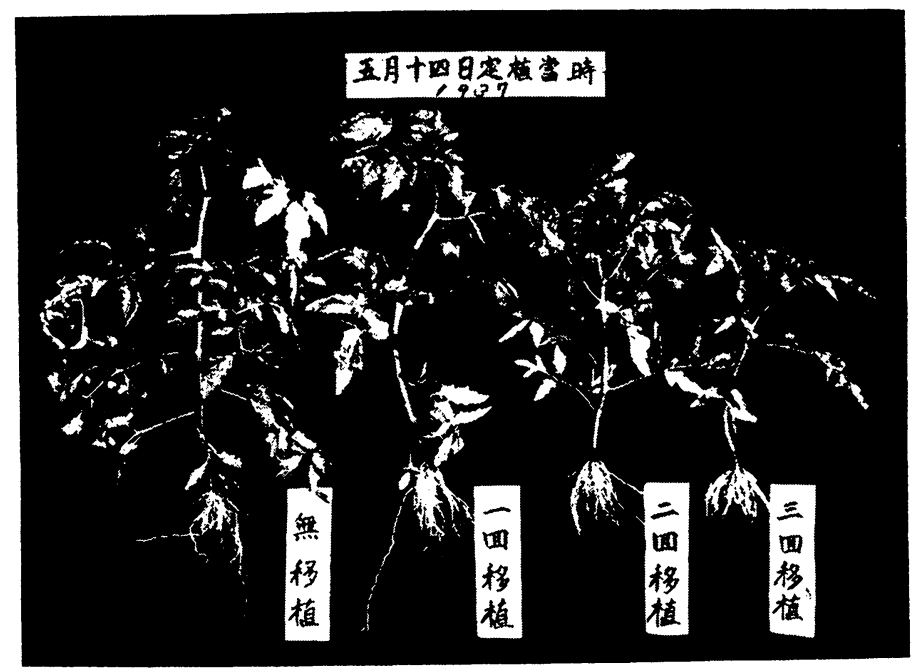

第 21 圖 定植當時 (5 月 14 日) に於ける各移植 區の苗の發育を示す

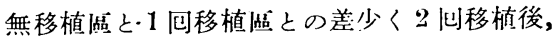
茼の發育の後れしを示す（1937．5 14）
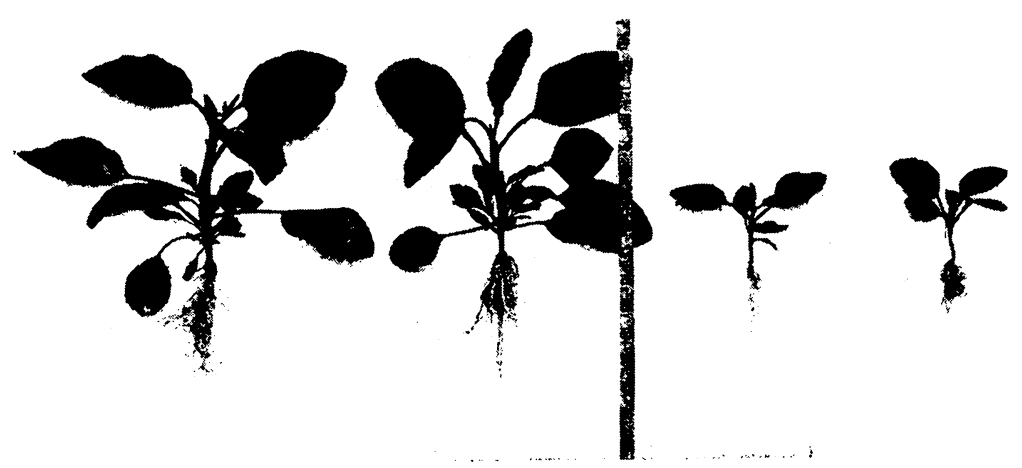

第 22 圖 定植當時 (5月 17 日) に於ける

各移植區の苗の發育を示す

無移植區と 1 回移植湂との差少く，2包

移植後は苗の筂育著しく後れて居る

(1937. 5. 17) 


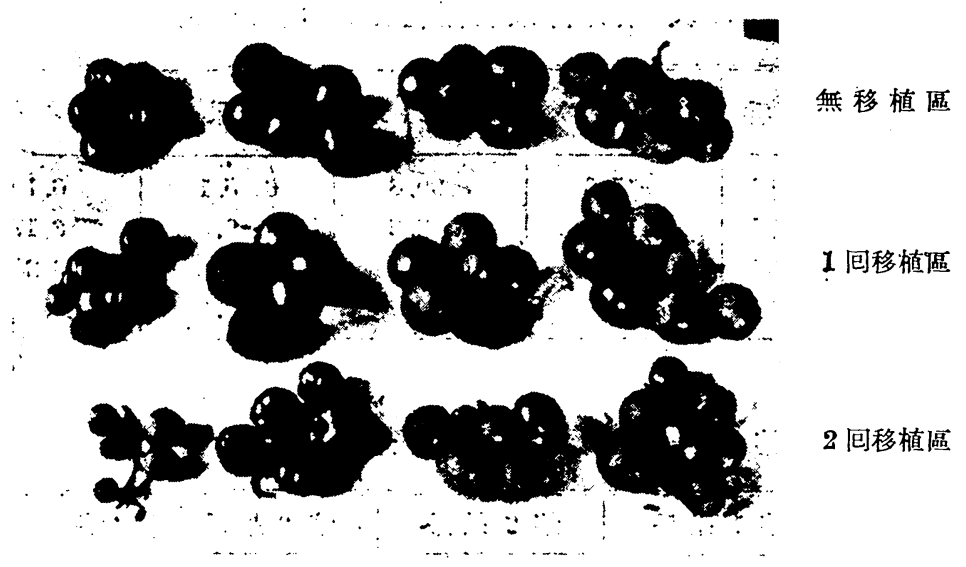

第 23 圖 各移植區の果房の發育を示す

向つて右より第 1 ，第 2 ，第 3 ，第 4 果房にして，無移植區と 1 回移植

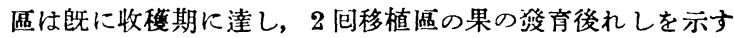

$(1937,8.13)$

以上諸結果は從來甘藍，䓟茌，花椰荣等に就て得られた結果之略々同樣，移 植操作は苗の發青を阴害し，移植包數を增す每に草丈，生體重及葉の枚數を減 少して居る。
(c) 要
約

以上諸結果を綜合すれば有苗中の移植操作は草丈，生體重，葉の枍數を減少 し花芽分化節位には殆んぼ影響を及仿して居ない。郎茄子，蕃茄が移植回數を 增寸每に花芽分化期の後れるのは移植操作に依つて一時生育が抑制され，一定 の分化節位 9-10 節飞達する事が後れ，引いては花牙形成期も後れるもの之見 る事が出來る。

（7）定植後の開花期，收檴期，收量飞及恃寸影響

育苗中の移植操作が最も必要視される所以のものは，移植と根群の配置郎定 植當時に於ける植急傷みとの關係如何であつて，移植回數の少き苗程植急傷み 多く，移植回數の多い苗程植急傷み少き事は從來屡了說かれて來た事である。 然ると今移植回數之定植後に於ける開花期, 收穫期, 收量との關係から見れば 次の通りである。

(a) 開花期及開花數飞及社響 
第 16 表 各果房最初開花日 (1936,トマト)

\begin{tabular}{|c|c|c|c|c|c|c|c|}
\hline 區 & 別 & 果 & & 第 1 果房 & 第 2 果房 & 第 3 果房 & 第 4 果房 \\
\hline 無 & 移 & 植 & 區 & $\begin{array}{l}\text { 月 } \\
5,15.6\end{array}$ & $\begin{array}{c}\text { 月 } \\
5,29.8\end{array}$ & $\begin{array}{l}\text { 月 } \\
6,5.1\end{array}$ & $\begin{array}{c}\mathrm{H} \\
6,15.4\end{array}$ \\
\hline 1 & 回 & 移 植 & 區 & $5,18.6$ & 6, 2. 6 & B, 9.6 & $6,17.6$ \\
\hline 2 & 回 & 移 植 & 區 & $5,19.4$ & $6,5.8$ & 6.14 .0 & $6,20.6$ \\
\hline 3 & 回 & 移 & 澏 & $5,26.0$ & $6,10.6$ & $6,20.0$ & $6,23.6$ \\
\hline
\end{tabular}

第 17 表 各果房開花數及結顆數 (1936,トマト)

\begin{tabular}{|c|c|c|c|c|c|c|c|c|}
\hline \multirow{2}{*}{ 區 番 } & \multicolumn{2}{|c|}{ 第 1 果房 } & \multicolumn{2}{|c|}{ 第 2 果房 } & \multicolumn{2}{|c|}{ 第 3 果房 } & \multicolumn{2}{|c|}{ 第 4 果房 } \\
\hline & 開花數 & 秙顆數 & 開花數 & 結顆數 & 開花數 & 結顆數 & 開花數 & 結顆數 \\
\hline 無移植區 & 8.4 & 5.0 & 8.4 & 5.6 & 6.0 & 4.6 & 7.2 & 5.4 \\
\hline 1 包移植區 & 6.6 & 4.6 & 5.6 & 4.4 & 7.2 & 5.0 & 7.2 & 5.0 \\
\hline 2 包移植區 & 5.8 & 4.4 & 5.0 & 4.2 & 8.2 & 5.4 & 5.2 & 4.4 \\
\hline 3 问移植區 & 5.0 & 3.6 & 5.0 & 4.0 & 6.0 & 44 & 5.0 & 4.4 \\
\hline
\end{tabular}

第 18 表 開花期比較 (1937,トマト)

\begin{tabular}{|c|c|c|c|c|c|c|}
\hline 澏 & 別 & 果 房 & 第 1 果房 & 第 2 果房 & 第 3 果房 & 第 4 果房 \\
\hline 無 & 移 & 植 & $\begin{array}{c}\text { म } \\
5,25.5\end{array}$ & $\begin{array}{l}\text { 月 } \\
6,5.0\end{array}$ & ค & $\begin{array}{l}4.71 \\
6,25.5\end{array}$ \\
\hline 1 & 回 移 & 多 植 區 & 29.0 & 5.0 & 25.5 & 23.5 \\
\hline 2 & 问 移 & 多 植 & $6,1.5$ & 12.5 & 27.5 & 29.5 \\
\hline 3 & 司 移 & 植 & 65 & 19.0 & $7,1.5$ & $7,4.0$ \\
\hline
\end{tabular}

第 19 表 各果房開花數, 結顆數, 實止步合表 (1937, トマト)

\begin{tabular}{|c|c|c|c|c|c|c|c|c|c|c|c|c|}
\hline & & 1 果 & & & 2 果 & & & 3 果 & & & 4 身 & \\
\hline 呬 & $\begin{array}{l}\text { 開 } \\
\text { 花 } \\
\text { 數 }\end{array}$ & $\begin{array}{l}\text { 結 } \\
\text { 顆 } \\
\text { 數 }\end{array}$ & $\begin{array}{l}\text { 實 } \\
\text { 歨 } \\
\text { 步 } \\
\text { 合 }\end{array}$ & $\begin{array}{l}\text { 䦕 } \\
\text { 花 } \\
\text { 數 }\end{array}$ & $\begin{array}{l}\text { 絬 } \\
\text { 顆 } \\
\text { 數 }\end{array}$ & $\begin{array}{l}\text { 惯 } \\
\text { 歨 } \\
\text { 步 } \\
\text { 合 }\end{array}$ & $\begin{array}{l}\text { 開 } \\
\text { 花 } \\
\text { 數 }\end{array}$ & $\begin{array}{l}\text { 結 } \\
\text { 顆 } \\
\text { 數 }\end{array}$ & $\begin{array}{l}\text { 霣 } \\
\text { 歨 } \\
\text { 步 } \\
\text { 合 }\end{array}$ & $\begin{array}{l}\text { 開 } \\
\text { 花 } \\
\text { 數 }\end{array}$ & $\begin{array}{l}\text { 結 } \\
\text { 顆 } \\
\text { 數 }\end{array}$ & $\begin{array}{l}\text { 筫 } \\
\text { 歨 } \\
\text { 步 } \\
\text { 合 }\end{array}$ \\
\hline 無 移植區 & 6.3 & 5.2 & 82.5 & 7.4 & 6.4 & 86.4 & 11.2 & 8.4 & 75.0 & 7.6 & 3.8 & 50.0 \\
\hline 1 包移植區 & 7.4 & 4.7 & 63.5 & 7.5 & 6.5 & 86.7 & 7.4 & 6.0 & 81.1 & 8.0 & 6.0 & 75.0 \\
\hline 2 回移植區 & 6.1 & 4.9 & 80.3 & 5.9 & 5.6 & 94.9 & 7.0 & 4.8 & 68.3 & 8.4 & 4.4 & 52.4 \\
\hline 3 包移植區 & 4.8 & 3.5 & 72.9 & 5.4 & 4.0 & 74.1 & 7.2 & 3.3 & 45.8 & 7.6 & 7.0 & 92.1 \\
\hline
\end{tabular}


第 20 表 1 番花--4 番花の開花日 (1936, 茄子)

\begin{tabular}{|c|c|c|c|c|c|c|c|}
\hline & 區 & 開花初日 & 本 & & 區 & 開花初日 & 平 \\
\hline \multirow{4}{*}{ 勫 } & & $\begin{array}{ll}9 & \text { 日 } \\
6, & 1\end{array}$ & $\begin{array}{l}\text { A } \\
6, \quad 3.4\end{array}$ & \multirow{4}{*}{$\begin{array}{l}\equiv \\
\text { 番 } \\
\text { 花 }\end{array}$} & 無移植區 & $\begin{array}{l}\text { 月 } \\
6,16\end{array}$ & 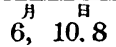 \\
\hline & 1 回移植區 & & 6.3 & & 1 包移植區 & 6,17 & $6,22.1$ \\
\hline & \multirow{2}{*}{3 回移植區 } & 6 & $6, \quad 15.8$ & & 2 包移植區 & 6,23 & $7, \quad 1.0$ \\
\hline & & 6 & $6,18.0$ & & 3 包移植區 & 6,22 & 3.9 \\
\hline \multirow{4}{*}{$\begin{array}{l}\text { 二 } \\
\text { 番 } \\
\text { 花 }\end{array}$} & 無移植澡 & 月, 13 & $\begin{array}{c}\text { 月 } \\
6,12.5\end{array}$ & \multirow{4}{*}{$\begin{array}{l}\text { 四 } \\
\text { 番 } \\
\text { 化 }\end{array}$} & 無移植區 & 月, ${ }^{H} 9$ & $\begin{array}{cc}\text { 月 } & { }^{\text {म }} \\
6, & 8.3\end{array}$ \\
\hline & 1 包移植區 & 6,17 & $6,20.6$ & & \multirow{2}{*}{$\begin{array}{l}1 \text { 包移植區 } \\
2 \text { 包移植區 }\end{array}$} & 6,20 & $6,11.5$ \\
\hline & 2 回移植澏 & 6,18 & $6,25.0$ & & & 6,20 & 1.0 \\
\hline & 3 包移植澏 & 6,16 & $6,24.1$ & & 3 包移植嵒 & 6,24 & 8.3 \\
\hline
\end{tabular}

借考 1. 本均は各區供試個體開花日の本均

2. 供試材料各區 15 本

第 21 表 開花期比較(第 1 花) (1937, 茄子)

\begin{tabular}{|c|c|c|c|c|}
\hline 區 & 別 & $\begin{array}{l}\text { 最初開 } \\
\text { 花期日 }\end{array}$ & $\begin{array}{l}\text { 本均阙 } \\
\text { 花期日 }\end{array}$ & $\begin{array}{l}\text { 播種後閵 } \\
\text { 花泛の所 } \\
\text { 泟旦 }\end{array}$ \\
\hline \multirow{2}{*}{\multicolumn{2}{|c|}{ 無 移植澏 }} & $\begin{array}{ll}\text { 月 } & \text { H } \\
6, & 5\end{array}$ & $\begin{array}{ll}\text { A } & \text { 日 } \\
6, & 7\end{array}$ & 84.6 \\
\hline & & $6, \quad 7$ & 6,9 & 86.0 \\
\hline \multicolumn{2}{|c|}{2 的移植温 } & 6,16 & 6,22 & 101.0 \\
\hline \multicolumn{2}{|c|}{3 回移植區 } & 6,24 & 6,25 & 103. 2 \\
\hline
\end{tabular}

以上諸結果に依れば蕃茄, 茄子共に 植总傷み少く移植包數少き區程開花期 早く開花數も多く，移植回數を增す每 に開花期後れ開花數を減じて居る。

(b) 收穫期及收量に及济す影響

第 22 表 各區に於ける各果房最初の收穫期 (1936, トマト)

\begin{tabular}{|c|c|c|c|c|c|c|c|}
\hline 區 & 別 & & 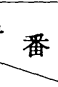 & 第 1 果房 & 第 2 果房 & 第 3 果房 & 第 4 果房 \\
\hline 無 & 移 & 植 & 區 & $\begin{array}{cc}\text { 月 } & \text { H } \\
7, & 5.4\end{array}$ & $\begin{array}{c}\text { 月 } \\
7,\end{array}$ & $\begin{array}{l}\text { A } \\
7, \quad 22.0\end{array}$ & $\begin{array}{c}\text { 月 } \\
7,\end{array}$ \\
\hline 1 & 回 移 & 植 & 區 & $7, \quad 9.4$ & $7, \quad 19.6$ & $7, \quad 23.0$ & 28.0 \\
\hline 2 & 间 移 & 植 & 藻 & $7, \quad 13.2$ & $7, \quad 21.6$ & 25.0 & 29.6 \\
\hline 3 & 回 移 & 植 & 區 & $7, \quad 18.2$ & $7, \quad 24.4$ & $7, \quad 27.6$ & $8, \quad 5.0$ \\
\hline
\end{tabular}

第 23 表 初期收穫表(7 月 5 日-7 月20日迄 $)(1936$, トマト $)$

\begin{tabular}{|c|c|c|c|}
\hline 別 & 收量 $(\mathrm{gr})$ & 顆 數 & 顆重 (gr) \\
\hline 無移植澏 & 910.6 & 6.2 & 141.28 \\
\hline 1 可移植區 & 684.0 & 5.2 & 133.46 \\
\hline 2 问移植成 & 599.8 & 4.2 & 135.40 \\
\hline 3 回移植區 & 459.2 & 3.2 & 124.86 \\
\hline
\end{tabular}

僻考 1 株賞平均
第 24 表 各區の總收量 (1936,トマト)

\begin{tabular}{|c|c|c|c|c|}
\hline 區 & 別 & 收量 (gr) & 顆 數 & 顆重 (gr) \\
\hline \multicolumn{2}{|c|}{ 無移植澏 } & 3053.8 & 28.6 & 106.764 \\
\hline \multicolumn{2}{|c|}{1 包移植區 } & 3142.2 & 32.0 & 96.124 \\
\hline \multicolumn{2}{|c|}{2 厄移植區 } & 3140.0 & 29.2 & 102.500 \\
\hline \multicolumn{2}{|c|}{3 包移植澏 } & 2830.8 & 25.8 & 114.544 \\
\hline
\end{tabular}

䚚考 8 月 24 日迄の 1 株當本均

註：供試本數每遌 5 株づっにして此 種闻場試驗としては少き憾有り 
第 25 表 初 期 生 (7月 8 日一-7月 20 日)

\begin{tabular}{|c|c|c|c|}
\hline 果房番 & 嵒 & 收量 (gr) & 顆 數 \\
\hline 第 1 果房 & 無 移植澏 & 614.8 & 4.7 \\
\hline " & 1 包移植區 & 464.9 & 4.4 \\
\hline " & 2 可移植區 & 489.0 & 4.3 \\
\hline " & 3 回移植洎 & 196.0 & 2.0 \\
\hline 第 2 果房 & 無移植湂 & 529.6 & 3.6 \\
\hline " & 1 包移植澏 & 216.2 & 1.5 \\
\hline "I. & 2 问移植澏 & 131.2 & 0.9 \\
\hline " & 3 问移植區 & 10.7 & 0.07 \\
\hline
\end{tabular}

備洘 1 株當平均
第 26 表 總 收 量 (1937, トマト)

\begin{tabular}{|c|c|c|}
\hline 區 & 顆 數 & 重量(gr) \\
\hline 無移植區 & 25.2 & 5133.44 \\
\hline 1 司移植區 & 25.4 & 1930.70 \\
\hline 2 包移植湢 & 23.6 & 439.48 \\
\hline 3 回移植區 & 20.4 & 3774.90 \\
\hline
\end{tabular}

借考 第 5 果房迄 1 株當平均

第 27 表 收 量 比 較 (1937, 茄子)

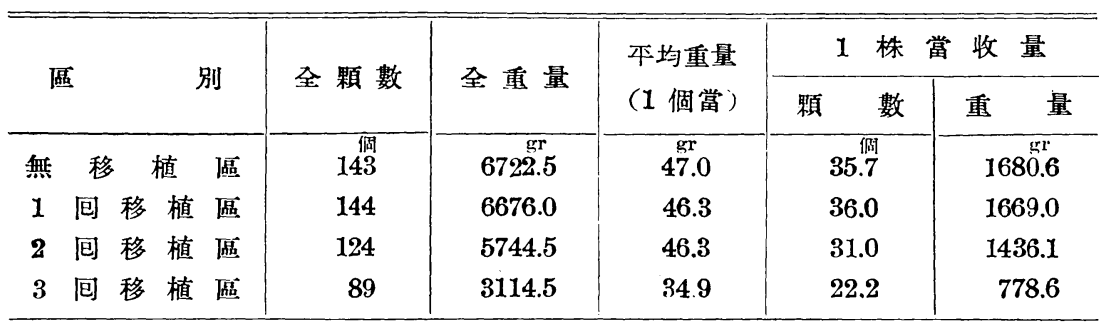

第 28 表 時期別收量比較 (1937, 茄子)

\begin{tabular}{|c|c|c|c|c|c|c|c|c|c|c|}
\hline \multirow{3}{*}{ 區 } & \multicolumn{2}{|c|}{ 收穫初期 } & \multicolumn{2}{|c|}{ 收穫前期 } & \multicolumn{2}{|c|}{ 收穫中期 } & \multicolumn{2}{|c|}{ 收穫後期 } & \multicolumn{2}{|c|}{ 收穕終期 } \\
\hline & \multicolumn{2}{|c|}{$\begin{array}{l}8 \text { 是 } \\
7,1 \\
\end{array}$} & \multicolumn{2}{|c|}{$\begin{array}{l}\text { 月 } \\
7,16\end{array}$} & \multicolumn{2}{|c|}{$\begin{array}{l}\text { 月 } \\
8, \\
1\end{array}$} & \multicolumn{2}{|c|}{ 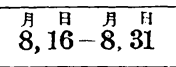 } & \multicolumn{2}{|c|}{$\begin{array}{l}\text { A } \\
9, \\
\end{array}$} \\
\hline & 個數 & 重量 & 個數 & 重 量 & 個數 & 重 量 & 個数 & 重 量 & 個數 & 重 量 \\
\hline 無移植區 & 11 & $\begin{array}{r}\mathrm{gr} \\
963.0\end{array}$ & 33 & $1419 \mathrm{gr} .0$ & 51 & $\begin{array}{r}\mathrm{gr} \\
2480.0\end{array}$ & $\begin{array}{l}\text { 倜 } \\
29\end{array}$ & 1110.5 & $\begin{array}{l}\text { 個 } \\
19\end{array}$ & $\begin{array}{r}\mathrm{gr} \\
750.0\end{array}$ \\
\hline 1 四移植區 & 7 & 560.0 & 53 & 2360.0 & 49 & 2278.5 & 24 & 997.5 & 11 & 480.0 \\
\hline 2 包移植區 & 8 & 428.0 & 25 & 1039.0 & 40 & 2198.0 & 33 & 1569.5 & 18 & 510.0 \\
\hline 3 包移植區 & 4 & 1660 & 19 & 770.0 & 20 & 941.5 & 25 & 1237.0 & 21 & 950.0 \\
\hline
\end{tabular}

註：各區 4 株合計

以上結果に依れば各區，供試株數の少き憾みはあつたが，茄子，蕃茄共に經 濟的見地より見て最も高價な初期生產は移植包數の少き區程多く，移植包數を 增す每に收量を減じ，栽培期間を通じを總收量に於ては各區間に著しん差が認 められなかつた。 
第 24 圖 各監に於ける溫床溫度 比較表 (1936, 茄子)

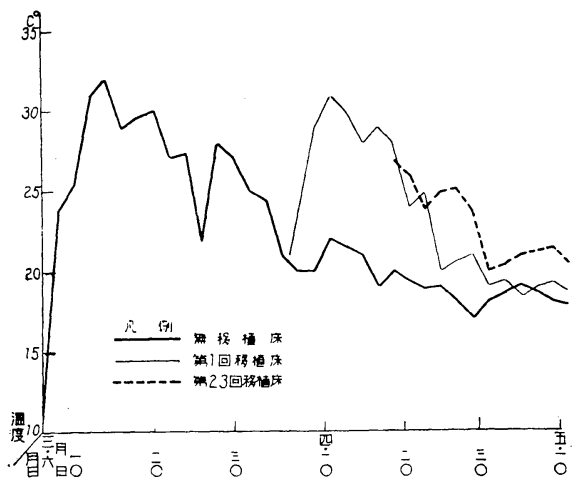

\section{（7）溫床溫度比較}

育苗中に於ける各區の溫床溫度 を比較すれば第 24 ，第 $25 ，$ 第 26 圖に示す通りである。

育苗中は移植の都度釀熱材料を 踏み込み，床を新たにし，無移植 區は播種當時の框を其儘使用した 從つて無移植區の溫度は實驗の中 涂加ら次第に低下 $\left(20^{\circ} \mathrm{C}\right.$ 以下) し て居るが，1 包以上の移植區は其 の 都度高溫 $\left(25^{\circ} \mathrm{C}\right.$ 內

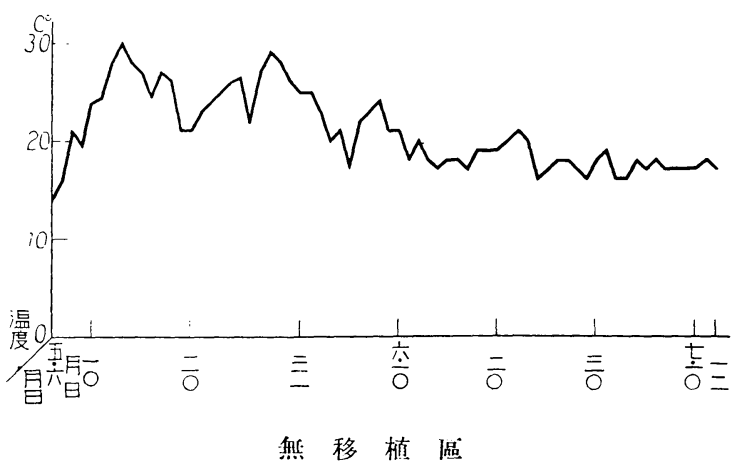
外）の框に移されて居 た即温度要素加ら云へ ば無移植區が最も惡く 移植を增す每江恰溫狀 態に䈯かれて居た譯で ある, 然るに苗の發育 は前述の通り無移植區 第 : 5 圖 各區に於ける溫床溫度比較表 (1936. トマト) 最も優れ移植包數を增 す短に劣つて居た。

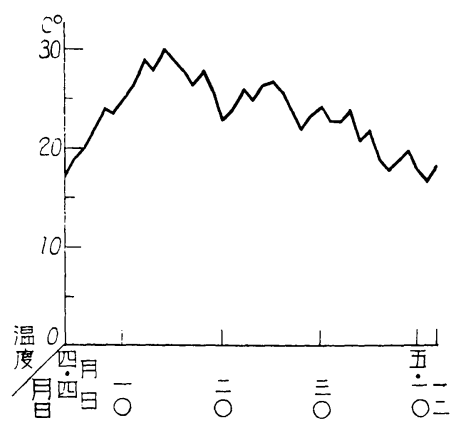

1 河䔟植 满

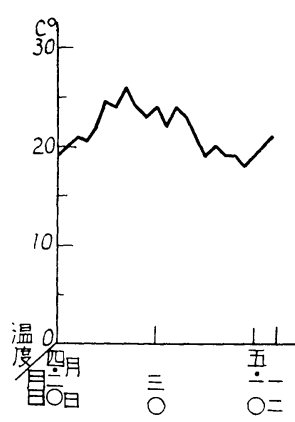

2 他移植澏

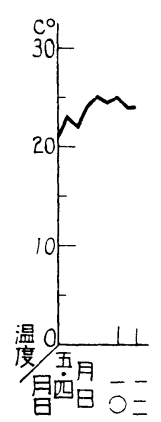

3 们移植闾

第 26 圖 各區に於ける溫床溫度比較表 (1936. トア々) 


\section{IV. 考察}

以上結果に依れば育苗中の移植操作は苗の發育を阻害して花牙分化期を後ら し，蕃茄に在つては花牙分化數さへ減少し，引いては開花期收穫期に惡影響を 及弫し從來動もすれば考へられ勝ちであつた積極的な效果は何等認められない ばかりで無く，寧ろ negative の影響を及ほして居る。此事は既に2，3の果樹 飞就々て Magness(1916), Harvey (1921), MUrneek (1928), Gardener(1923), 川口氏 (1932)，三輪氏(1935)(1937)等が摘葉は果樹類の花牙分化に惡影響を及 㾁す事を報告して居るのと略ら同意義に見る可きであつて,移植に依る斷根が， 苗の發育を阻害し，花牙分化を後らす居のと見られる。筆者等は別に鉢植の材 料に就んて人爲的に各種の断根區を設け其の影響を調へて居るが移植の場合と 略々同結果を得て居る。

今，立場を變へて育苗の實際方面から見れば，移植の都度，醸熱材料の踏込 み，床土の入れ換へを行ひ，移植作業其事は又育苗中の大牛の勞勞纯むるも のであつて，今，夫れ等の作業を省く事に低つて可なり樂な育苗を行ふ事が出 來る而己ならず苗其物にも好影響を及仿すものである。

以前，地方地方に育苗專業家があつて，遠隔な地方に苗の輸途を行つを時代 には多少の不便と不合理を忍んでも移植包數を多くして固い苗を作る必要があ つたものとも見られるが，各農家個々に育苗を行ふ現今に在つては，勉めて移 植包數を減じ，株間を $5-6$ 寸に取り，定植に當り允分の床土を付け，叮寧な 取扱ひを爲す事が肝要な事炿と思ふ。份活胡瓜，南瓜等蒙性の苗物は根群の性 質より見て2一3 包の移植の行はれる事も餘儀無い事であらう。

\section{v. 摘要及結 論}

1. 育苗中の移植操作が茄子・蕃茄の花芽分化期, 花芽の發育, 開花期, 收 穫期，收量に及洼す影響に就いて實驗を行つた。

2. 茄子・蕃茄共に播種後 30-40 日に第 1 番花を形成し, 溫床育苗中に蕃 茄は第 3 果房, 茄子は第 5 , 第 6 番花迄形成されて居る。

3. 育苗中の移植操作は花芽分化期, 分化數に影響を及代し, 移植包數の多 レもの程恶影響を與へて居る。

4. 移植包數の多い苗程開花期, 收穫期多後れ從來考へられて居たやうな移 
植の積極的效果は何等認められなん。

5. 育苗中の移植包數を少くする事に依つて多分の管力を省く事が出來る而 巳ならす，苗其物にも好影響を與へて居る。

6. 以上の點から茄子・蕃茄の移植包數は今後 1 包から 2 包を限度に改む可 きものだと思ふ。

本實驗は小島, 野崎, 溫井氏等の協力に待つ處多く, 平岡, 小出君等の手を煩はす 事多かつた，厚く感謝の意を表はす。

\section{VI. 引用 文 獻}

（1）淺見與七 (1934)：蔬穼の移植に關する研究，園藝に關する研究報告，櫻會，304一 316.

(2) Cranefield, F. (1899): The effect of transplanting on time of maturity. Ann. Rept. Wis. (Quoted by Thompson.)

(3) Gardner, V. (1923): Studies in the nutrition of the strawberry. Missouri Agr. Exp. Sta. Bull. 57.

(4) Harvey, E. and Murneek, E. (1921): The relation of carbohydrates and nitrogen to the behavior of apple spurs. Ore. Agr. Exp. Sta. Bull. 176.

（5）石黑嘉門 (1935):：育苗上矿了障子と油障子との差異亚びに移植问數の相違が加子の

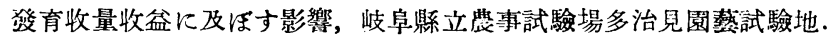

(6) Jones, H. (1922): Tomatoes for market and canning. Md. Agr. Exp. Sta. Bull. 248.

（7）川口正英 (1932)：梨，桃に於ける花芽分化期及び其の前後に於ける枝梢の摘葉が花

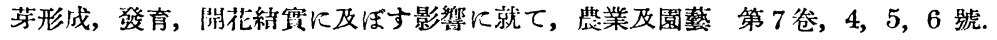

(8) Lloyd, J. and Brooks, I. (1910): Growing tomatoes for early market. Ill. Bull. 144.

(9) Looms, W. (1925): Studies in the transplanting of vegetable plants. Cornell. Univ. Agr. Exp. Sta. Mem. 87.

(10) Magness, G. (1916): The influence of summer pruning on bud development in the apple. Oreg. Agr. Exp. Sta. Bull. 139.

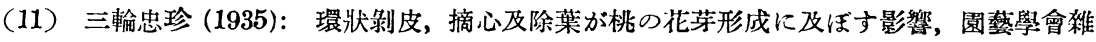
誌, 第 6 尖, 第 2 號.

（12）- (1937)：環狀貘皮，摘心及除葉が桃の花芽形成に及ぼす影響，圍藝學研究 集錄 第2輯.

(13) Murneek, A. (1928): Effect of pruning on the carbohydrate-nitrogen ratio in the tomato. Proc. Amer. Soc. Hort. Sci. Vol. 24.

（14）志佐 誠 (1937): 茄苗の移植が第 1 花の絬菑に及ぼす影響, 園藝學研究集淥第 2 輯.

(15) Thомpson, M. (1923): Vegetable Crops.

(16) Weaver, E. and E. Bruner (1927): Root development of vegetable crops.

(17) Weater, E. and E. Clement (1929): Plant ecology. 